\title{
ISOLASI DAN KARAKTERISASI ENZIM AMILASE DARI BIJI NANGKA (Artocarpus heterophillus)
}

\author{
Nita Puspita TAZKIAH ${ }^{1}$, Tina DEwi Rosahdi ${ }^{1 *}$, DAN ASEP SUPRIADIN ${ }^{1}$ \\ ${ }^{1}$ Jurusan Kimia, Fakultas Sains dan Teknologi, UIN Sunan Gunung Djati Bandung, \\ Jl. A.H. Nasution No. 105, Bandung \\ *Email korespondensi: tina_dr@uinsgd.ac.id
}

\begin{abstract}
Informasi Artikel Abstrak/Abstract
Riwayat Naskah : Diterima pada 24

Mei 2017

Diterima setelah direvisi pada 28 Juni 2017

Diterbitkan pada 30

Juni 2017

Kata Kunci:

Amilase; biji nangka;

Amilase merupakan enzim perombak pati yang dibutuhkan oleh tubuh. Amilase dapat diisolasi dari berbagai tumbuhan, misalnya biji-bijian. Pada penelitian ini amilase diisolasi dari biji nangka, karena biji nangka tidak banyak dikonsumsi sehingga menjadi limbah. Penelitian ini bertujuan untuk mengkarakterisasi amilase dari biji nangka. Amilase diekstraksi dengan buffer fosfat $50 \mathrm{mM}$ pada $\mathrm{pH}$ 7,5. Amilase difraksinasi dengan metode salting out dengan ammonium sulfat $\left(\mathrm{NH}_{4}\right)_{2} \mathrm{SO}_{4}$, kemudian didialisis dengan buffer fosfat. Aktivitas amilase dari biji nangka ditentukan dengan menggunakan metode Fuwa dan konsentrasi protein diukur dengan metode Bradford. Aktivitas spesifik yang paling tinggi diperoleh pada tingkat kejenuhan 50\% dengan aktifitas spesifik 2,12 U/mg. pH optimum amilase berada padapH 6, dengan aktivitas spesifik sebesar 2,52 Unit/mg, sedangkan suhu optimumnnya berada di suhu $50^{\circ} \mathrm{C}$ dengan aktivitas spesifik 2,52 Unit/mg.
\end{abstract}

dialysis; metode

Fuwa; metode

Bradford; salting out

Keywords: Amilase; jackfruit seeds; dialysis; Fuwa method; Bradford method; salting out
Amylase is a starch enzyme needed by the body. Amylase can be isolated from various plants, such as seeds. In this study amylase was isolated from jackfruit seeds, because jackfruit seeds were not consumed so much that it became waste. This study aims to characterize amylase from jackfruit seeds. Amylase was extracted with $50 \mathrm{mM}$ phosphate buffer at $\mathrm{pH}$ 7.5. Amylase is fractionated by salting out method with ammonium sulfate $\left(\mathrm{NH}_{4}\right)_{2} \mathrm{SO}_{4}$, then dialyzed with phosphate buffer. Amylase activity from jackfruit seeds was determined using the Fuwa method and protein concentration was measured by Bradford method. The highest specific activity was obtained at 50\% saturation level with specific activity $2.12 \mathrm{U} / \mathrm{mg}$. The optimum $\mathrm{pH}$ of amylase is at 6, with a specific activity of 2.52 Units $/ \mathrm{mg}$, while the optimum temperature is at $50^{\circ} \mathrm{C}$ with a specific activity of 2.52 Units $/ \mathrm{mg}$.

\section{PENDAHULUAN}

Enzim merupakan biomolekul yang berfungsi untuk mempercepat jalannya reaksi metabolisme di dalam tubuh makhluk hidup tanpa mempengaruhi keseimbangan reaksi. Enzim tidak ikut bereaksi, struktur enzim tidak berubah baik sebelum dan sesudah reaksi [1].

Enzim bekerja pada substrat (reaktan) dan mengubahnya menjadi hasil (produk). Daerah pada enzim yang mengikat suatu substrat disebut dengan sisi aktif. Tingkat selektivitas yang tinggi memungkinkan sel mengendalikan reaksi-reaksi metabolisme dengan mengatur bentuk dan jumlah enzim yang dihasilkan [2].

Enzim yang berperan dalam mengubah karbohidrat kompleks adalah karbohidrase, amilase, dan selulase. Amilase adalah enzim yang berfungsi memecah zat tepung dan polisakarida lainnya menjadi monosakarida, bentuk gula yang dapat diserap tubuh. Selain itu, kini amilase banyak digunakan pada proses industri.
Amilase terdiri dari tiga jenis, yaitu: $\alpha$ amilase, $\beta$-amilase dan $\gamma$-amilase [3]. $\alpha$-amilase terdapat dalam saliva (ludah) dan pankreas. Enzim ini memecah ikatan 1-4 yang terdapat dalam amilum dan disebut endo amilase karena memecah bagian dalam atau bagian tengah molekul amilum. $\beta$-amilase terdapat pada tumbuhan dan dinamakan ekso amilase, sebab memecah dua unit glukosa yang terdapat pada ujung molekul amilum secara berurutan sehingga pada akhirnya membentuk maltosa. $\gamma$-amilase terdapat dalam hati. Enzim ini dapat memecah ikatan 1-4 dan 1-6 pada glikogen dan menghasilkan glukosa [3].

Amilase sangat berperan dalam industri pembuatan roti, sirup, tekstil dan farmasi [4] Seiring dengan meningkatnya penggunaan amilase, maka perlu dicari sumber amilase dari bahan baku yang mudah didapat. Salah satu bahan yang memiliki potensi untuk dieksploitasi sebagai sumber enzim amilase adalah biji nangka. 
Pada penelitian ini digunakan biji nangka sebagai sumber untuk mendapatkan amilase. Biji nangka dipilih karena memiliki kadar amilum yang cukup tinggi, yaitu 36,7 gram per $100 \mathrm{~g}$ biji nangka. Pemilihan biji nangka juga merupakan bentuk pemanfaatan limbah.

\section{EKSPERIMEN}

\section{Material}

Bahan-bahan yang digunakan dalam penelitian ini adalah biji nangka, buffer fosfat 50 $\mathrm{mM} \mathrm{pH}(5,6$, dan 7), larutan iodium (mengandung $\mathrm{KI} 2 \%$ dan $\left.\mathrm{I}_{2} 0,2 \%\right), \quad \mathrm{HCl} 1 \mathrm{M}$, akuades, ammonium sulfat (p.a, merck), pati (p.a, merck), membran selofan (SERVA diameter $21 \mathrm{~mm}$ ), benang kasur, pereaksi Coomassie Briliant Blue (pereaksi Bradford), standar BSA (Bovine SerumeAlbumin).

\section{Instrumentasi}

Instrumen yang digunakan pada penelitian ini adalah spektrofotometri UV visible (Agilent Technologies Cary $60 \mathrm{UV}-\mathrm{V}$ is

\section{Prosedur Kerja}

\section{Ekstraksi Amilase}

Biji nangka dibersihkan kemudian sebanyak 300 gram biji nangka diblender dengan ditambahkan $600 \mathrm{~mL}$ buffer fosfat $50 \mathrm{mM} \mathrm{pH} \mathrm{7,5}$ selama 10 menit. Bubur biji nangka disaring dan didekantasi sehingga terpisah antara ekstrak dan endapan pati. Ekstrak selanjutnya disentrifugasi dengan putaran $4000 \mathrm{rpm}$ selama 15 menit [5]. Supernatan yang diperoleh diuji aktivitas dan konsentrasi protein totalnya. Supernatan yang dihasilkan disebut sebagai ekstrak kasar.

\section{Uji Aktivitas dan Konsentrasi Amilase dari ekstrak kasar}

Aktivitas ekstrak kasar diuji menggunakan metode Fuwa. Sebanyak $250 \mu \mathrm{L}$ larutan pati 3\% dalam buffer fosfat $50 \mathrm{mM}$ pH 7,5 ditambah 250 $\mu \mathrm{L}$ larutan enzim dan diinkubasi pada suhu $50{ }^{\circ} \mathrm{C}$ selama 10 menit. Campuran ditambah $250 \mu \mathrm{L}$ larutan $\mathrm{HCl} 1 \mathrm{M}, 250 \mu \mathrm{L}$ larutan iodium (mengandung 2\% KI dan 0,2\% $\mathrm{I}_{2}$ ) dan diencerkan dengan akuades hingga volume $5 \mathrm{~mL}$. Absorbansinya diukur pada panjang gelombang $600 \mathrm{~nm}[6]$.

Kadar protein total diuji dengan metode Bradford. Sebanyak $500 \mu \mathrm{L}$ ekstrak enzim dan 500 $\mu \mathrm{L}$ pereaksi Bradford divortex, diinkubasi selama 5-10 menit pada suhu ruang. Kemudian diukur pada absorbansi $595 \mathrm{~nm}$ [7]. Kadar protein total ditentukan berdasarkan kurva standar protein. Standar protein yang digunakan yaitu BSA.

\section{Fraksinasi Amilase dengan Salting Out}

Larutan enzim dimasukkan ke dalam tabung ditambahkan larutan ammonium sulfat hingga mencapai $50 \%$ jenuh. Campuran diaduk dan didiamkan selama 5 menit pada suhu kamar, kemudian disentrufugasi selama 15 menit dengan kecepatan $4000 \mathrm{rpm}$. Supernatan dipindahkan ke dalam tabung yang baru. Endapan yang terbentuk disebut fraksi $50 \%$ ammonium sulfat jenuh. Endapan dilarutkan dengan buffer fosfat $50 \mathrm{mM}$ pH 7,5. Garam ammonium sulfat ditambahkan ke dalam supernatan dari tahap sebelumnya hingga mencapai $55 \%$ jenuh. Campuran diaduk dan didiamkan selama 5 menit pada suhu kamar. Campuran disentrifugasi selama 15 menit. Supernatan dipindahkan ke dalam tabung baru. Endapan terbentuk disebut fraksi 55\% ammonium sulfat jenuh. Endapan dilarutkan dengan buffer fosfat $\mathrm{mM} \mathrm{pH} \mathrm{7,5.} \mathrm{Garam} \mathrm{ammonium} \mathrm{sulfat}$ ditambahkan ke dalam supernatan dari tahap sebelumnya hingga mencapai $60 \%$ jenuh. Campuran diaduk dan didiamkan selama 5 menit pada suhu kamar. Campuran disentrifugasi selama 15 menit. Supernatan dipindahkan ke dalam tabung baru. Endapan yang terbentuk disebut dengan fraksi $60 \%$ ammonium sulfat jenuh. Endapan dilarutkan dengan buffer fosfat $50 \mathrm{mM}$ pH 7,5, kemudian setiap fraksi ammonium sulfat yang dihasilkan didialisis dengan menggunakan buffer fosfat $50 \mathrm{mM} \mathrm{pH} \mathrm{7,5} \mathrm{selama} 3$ jam, dengan mengganti larutan buffer fosfat setiap 1 jam sekali.

\section{Pemurnian Amilase dengan Dialisis}

Membran selofan direbus dalam buffer fosfat $50 \mathrm{mM} \mathrm{pH} \mathrm{7,5} \mathrm{selama} 5$ menit setelah larutan buffer mendidih. Salah satu ujung selofan diikat dengan benang, kemudian larutan enzim tiap fraksi dimasukkan ke dalam masing-masing membran selofan yang berbeda. Selanjutnya proses dialisis dilakukan dengan merendam kantong selofan berisi larutan enzim dalam buffer fosfat $50 \mathrm{mM} \mathrm{pH} \mathrm{7,5} \mathrm{sambil} \mathrm{diaduk} \mathrm{menggunakan}$ magnetic stirrer pada suhu $5{ }^{\circ} \mathrm{C}$ dan setiap 1 jam sekali larutan buffer fosfat harus diganti selama 3 jam [8]. Larutan enzim yang telah mengalami dialisis, diuji kembali aktivitas dan kadar protein totalnya. Prosedur yang digunakan sama dengan uji aktivitas amilase dan kadar protein total dari ekstrak kasar. 
Karakterisasi Enzim Amilase

\section{Pengaruh pH Terhadap Aktivitas Enzim Amilase}

Sebanyak $250 \mu \mathrm{L}$ larutan pati $3 \%$ dalam buffer fosfat $50 \mathrm{mM}(\mathrm{pH}$ 5,6,7, dan 8), ditambahkan $250 \mu \mathrm{L}$ larutan enzim, ditambahkan $250 \mu \mathrm{L} \mathrm{HCl} 1 \mathrm{M}, 250 \mu \mathrm{L}$ larutan Iodium (mengandung $2 \% \mathrm{KI}$ dan $0,2 \% \mathrm{I}_{2}$ ) dan diencerkan dengan akuades hingga volume $5 \mathrm{~mL}$. Absorbansinya diukur pada panjang gelombang $600 \mathrm{~nm}$.

\section{Pengaruh Suhu terhadap Aktivitas Enzim Amilase}

Sebanyak $250 \mu \mathrm{L}$ larutan pati $3 \%$ dalam buffer $50 \mathrm{mM} \mathrm{pH}$ 7,5 ditambahkan $250 \mu \mathrm{L}$ larutan enzim dan diinkubasi pada suhu $40{ }^{\circ} \mathrm{C}, 50{ }^{\circ} \mathrm{C}, 60$ ${ }^{\circ} \mathrm{C}$, dan $70{ }^{\circ} \mathrm{C}$ selama 10 menit. Kemudian

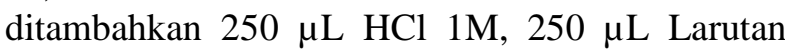
Iodium (mengandung $2 \% \mathrm{KI}$ dan $0,2 \% \mathrm{I}_{2}$ ) dan diencerkan dengan akuades hingga volume $5 \mathrm{~mL}$. Absorbansinya diukur pada panjang gelombang $600 \mathrm{~nm}$.

\section{HASIL DAN PEMBAHASAN}

\section{Ekstraksi Amilase dari Biji Nangka}

Ekstraksi dilakukan dengan cara homogenisasi dengan blender menggunakan larutan buffer fosfat $50 \mathrm{mM} \mathrm{pH} \mathrm{7,5.} \mathrm{Penggunaan}$ larutan buffer fosfat adalah untuk menghindari terjadinya enzim terdenaturasi akibat $\mathrm{pH}$ yang berubah. Pemilihan $\mathrm{pH}$ 7,5 karena mendekati netral. Proses penghalusan dimaksudkan untuk merusak jaringan dan dinding sel, sehingga isi sel dapat keluar. Pada proses penghalusan ini dilakukan pada suhu dingin, yaitu untuk menjaga agar enzim tidak terdenaturasi. Biji nangka yang telah hancur kemudian didekantasi untuk memisahkan larutan dengan endapan.

Larutan yang diperoleh kemudian disentrifugasi. Sentrifugasi bertujuan untuk memisahkan larutan berdasarkan berat molekul protein penyusun organel sel. Hasil dari sentrifugasi ekstrak kasar berada di bagian atas (supernatan), sementara organel-organel sel mengendap dibagian bawah. Amilase yang didapat merupakan amilase ekstrak kasar, yang kemudian perlakuannya dibedakan yaitu salah satu sampel ekstrak kasar disimpan pada suhu $4{ }^{\circ} \mathrm{C}$ dan sampel yang lainnya disimpan pada suhu $-20{ }^{\circ} \mathrm{C}$. Pada kedua ekstrak kasar amilase ini kemudian dilakukan uji aktivitas amilase dan uji kadar protein total.
Uji aktivitas amilase menggunakan metode Fuwa. Ekstrak kasar enzim ditambahkan dengan larutan pati kemudian di panaskan pada suhu $50{ }^{\circ} \mathrm{C}$ selama 10 menit. Pemanasan bertujuan agar enzim mencapai suhu optimum yang akan meningkatkan kecepatan reaksi. Kemudian campuran ditambahkan $\mathrm{HCl}$ untuk menghentikan aktivitas enzim, dan ditambahkan larutan KI yang akan menghasilkan kompleks heliks berwarna biru antara amilosa dengan reagen iodin [9]. Pada sampel yang diuji warna biru berkurang karena sebagian pati telah terhidrolisis oleh amilase. Konsentrasi pati yang telah dihidrolisis oleh amilase dihitung dengan menggunakan kurva standar pati. Hasil penentuan aktivitas amilase ekstrak kasar dapat dilihat pada Tabel 1.

Aktivitas amilase dari ekstrak biji nangka yang disimpan pada suhu $4{ }^{\circ} \mathrm{C}$ sebesar $0,56 \mathrm{U} / \mathrm{mL}$, sedangkan sampel amilase ekstrak kasar yang disimpan pada suhu $-20{ }^{\circ} \mathrm{C}$ aktivitasnya 0,60 $\mathrm{U} / \mathrm{mL}$. Aktivitas amilase yang disimpan pada suhu $-20{ }^{\circ} \mathrm{C}$ lebih besar bila dibandingkan dengan aktivitas amilase yang disimpan pada suhu $4{ }^{\circ} \mathrm{C}$. Hal ini dikarenakan pada suhu $-20{ }^{\circ} \mathrm{C}$ enzim lebih terjaga dengan adanya proses pembekuan, enzim menjadi inaktif. Sedangkan pada ekstrak kasar yang disimpan pada suhu $4{ }^{\circ} \mathrm{C}$ amilase kurang stabil sehingga nilai aktivitasnya lebih kecil.

Pada penentuan kadar protein total menggunakan metode Bradford, larutan ekstrak kasar ditambahkan dengan reagen Bradford yaitu CBB (Coomossie Brilliant Blue), dan membentuk kompleks CBB-protein yang berwarna biru. Pembentukan kompleks karena adanya ikatan antara pewarna CBB dengan residu arginin, histidin, lisin, tirosin, triptofan, fenilalanin dan residu asam amino hidrofobik yang ada pada protein sehingga menghasilkan warna biru. Warna biru tersebut kemudian diukur menggunakan spektrofotometer UV-Vis pada panjang gelombang $595 \mathrm{~nm}$ [10].

Bouvine Serum Albumin (BSA) digunakan sebagai standar untuk pengukuran kadar protein karena tingkat kemurniannya tinggi. Hasil penentuan kadar protein total selanjutnya digunakan untuk menghitung aktivitas spesifik amilase ekstrak kasar. Perhitungan aktivitas spesifik yaitu aktivitas enzim dibagi dengan hasil dari kadar protein total, dapat dilihat pada Tabel 1.

Pada Tabel 1 unit aktivitas enzim dinyatakan dengan $1 \mathrm{mg}$ pati yang terhidrolisis oleh $25 \mu \mathrm{L}$ enzim selama 10 menit pada suhu 50 ${ }^{\circ} \mathrm{C}$. Dari perhitungan didapatkan nilai aktivitas spesifik untuk amilase ekstrak kasar yang disimpan pada suhu $4{ }^{\circ} \mathrm{C}$ yaitu $1,50 \mathrm{U} / \mathrm{mg}$, sedangkan aktivitas spesifik amilase ekstrak kasar yang disimpan pada suhu $-20^{\circ} \mathrm{C}$ yaitu $1,99 \mathrm{U} / \mathrm{mg}$. 
Tabel 1. Data hasil penentuan kadar protein total dan aktivitas spesifik amilase ekstrak kasar

\begin{tabular}{cccc}
\hline Sampel & $\begin{array}{c}\text { Aktivitas } \\
\text { Enzim } \\
\text { Unit/mL }\end{array}$ & $\begin{array}{c}\text { Kadar } \\
\text { Protein } \\
(\mathrm{mg} / \mathrm{mL})\end{array}$ & $\begin{array}{c}\text { Aktivitas } \\
\text { Spesifik } \\
(\mathrm{U} / \mathrm{mg})\end{array}$ \\
\hline Suhu $4{ }^{\circ} \mathrm{C}$ & 0,56 & 0,372 & 1,50 \\
Suhu $-20{ }^{\circ} \mathrm{C}$ & 0,60 & 0,302 & 1,99 \\
\hline
\end{tabular}

\section{Fraksinasi dengan Ammonium Sulfat (Salting out)}

Ekstrak kasar enzim yang diperoleh selanjutnya dipisahkan dengan fraksinasi bertingkat. Ekstrak kasar enzim yang digunakan yaitu ekstrak kasar enzim yang disimpan pada suhu $-20^{\circ} \mathrm{C}$, karena memiliki nilai aktivitas spesifik yang lebih besar.

Proses fraksinasi menggunakan garam ammonium sulfat. Garam yang paling umum digunakan untuk pemurnian enzim adalah garam yang meningkatkan hidrasi daerah hidrofil dan dehidrasi daerah hidrofob pada protein. Anion yang masuk kedalam kategori ini adalah anion polivalen seperti sulfat. Untuk kation dipilih yang tidak memiliki kemungkinan untuk mengadakan kompleks dengan protein, maka semua ion metal polivalen tidak dapat digunakan [10]. Dengan penambahan ammonium sulfat, ion-ion garam akan bersaing dengan protein untuk berikatan dengan molekul air sehingga protein-protein enzim banyak yang terendapkan (salting out).

Penggunaan garam ammonium sulfat sebagai salting out karena garam ini dapat merusak mantel air yang terdapat disekitar enzim (protein) sehingga protein akan membentuk koagulan. Selain itu ammonium sulfat memiliki tingkat kelarutan didalam air yang sangat tinggi, tidak mengandung zat-zat yang toksik terhadap kebanyakan enzim, harganya relatif murah dan jika digunakan dalam jumlah banyak dapat sebagai stabilisator enzim itu sendiri [11].

Fraksinasi bertingkat dengan garam ammonium sulfat dilakukan pada tingkat kejenuhan 50\% (fraksi I), 55\% (fraksi II), dan 60\% (fraksi III). Ketiga fraksi ini selanjutnya disentrifugasi dengan kecepatan 4000 rpm dengan waktu 15 menit. Endapan yang diperoleh kemudian di larutkan dengan buffer fosfat $50 \mathrm{Mm}$ $\mathrm{pH}$ 7,5 kemudian di dialisis.

\section{Dialisis dalam Membran Selofan}

Proses dialisis bertujuan untuk menghilangkan kadar garam ammonium sulfat yang ditambahkan pada proses fraksinasi. Dialisis dilakukan dengan menggunkan membran selofan yang dapat dilalui oleh partikel-partokel kecil, seperti ion-ion garam, tetapi dapat menahan molekul enzim.

Sebelum digunakan membran selofan direbus dengan menggunakan buffer fosfat $\mathrm{pH}$ 7,5 $50 \mathrm{mM}$. Proses perebusan yaitu untuk membuka membran selofan yang tertutup serta menghilangkan lemak serta pengotor lainnya. Proses dialisis dilakukan dengan merendam membran selofan yang telah diisi larutan enzim hasil fraksi dengan larutan buffer fosfat $\mathrm{pH} 7,5$ dengan konsentrasi $50 \mathrm{mM}$ selama 3 jam, sambil diaduk dengan menggunakan magnetic striter pada suhu $5^{\circ} \mathrm{C}$, mengingat enzim mudah terdenaturasi.

Larutan buffer fosfat diganti setiap 1 jam sekali, hal ini bertujuan agar ion-ion garam yang sudah melewati membran selofan tidak kembali masuk kedalam membran dan hal ini merupakan salah satu cara untuk mempercepat pergerakan molekul [12].

Hasil dari proses dialisis disebut sebagai fraksi amilase. Fraksi amilase ini kemudian diuji aktivitas enzim dengan metode Fuwa dan uji kadar protein totalnya dengan metode Bradford dan hasilnya digunakan untuk menghitung aktivitas spesifik amilase seperti pada Tabel 2.

Tabel 2. Data hasil penentuan kadar protein dan aktivitas spesifik enzim setelah dialisis

\begin{tabular}{llll}
\hline $\begin{array}{l}\text { Fraksinasi dengan } \\
\text { Ammonium } \\
\text { Sulfat }\end{array}$ & $\begin{array}{l}\text { Aktivitas } \\
\text { Enzim } \\
\text { Unit/mL }\end{array}$ & $\begin{array}{l}\text { Protein } \\
\text { Total } \\
(\mathrm{mg} / \mathrm{mL})\end{array}$ & $\begin{array}{l}\text { Aktivitas } \\
\text { Spesifik } \\
\text { (Unit/mg) }\end{array}$ \\
\hline Fraksi I $(50 \%)$ & 0,16 & 0,0755 & 2,12 \\
Fraksi II $(55 \%)$ & 0,12 & 0,063 & 1,904 \\
Fraksi III $(60 \%)$ & 0,08 & 0,048 & 1,67 \\
\hline
\end{tabular}

Dari Tabel 2 didapat aktivitas enzim spesifik tertinggi yaitu pada fraksi I dengan kejenuhan ammonium sulfat $50 \%$ yaitu 2,12 Unit/mg, sedangkan aktivitas spesifik enzim terendah yaitu pada fraksi III dengan tingkat kejenuhan ammonium sulfat $60 \%$ yaitu 1,67 Unit/mg. Pada penelitian ini fraksi 50\% memiliki aktivitas spesifik lebih besar, hal ini menunjukkan pada fraksi ini enzim telah terendapkan dengan baik.

Aktivitas spesifik pada fraksi amilase meningkat bila dibandingkan dengan nilai aktivitas spesifik ekstrak kasar. Peningkatan aktivitas spesifik menunjukkan enzim yang diperoleh semakin murni.

\section{Karakterisasi Amilase dari Bïi Nangka}

Penentuan $\mathrm{pH}$ optimum dilakukan menggunakan metode Fuwa seperti pada uji 
aktivitas amilase. Untuk karekterisasi $\mathrm{pH}$ terhadap aktivitas enzim digunakan buffer fosfat pada berbagai yaitu $\mathrm{pH} 5,6,7$, dan 8 .

Untuk penentuan suhu optimum digunakan metode Fuwa. Sebelum dilakukan pengujian, sampel yang ditambahkan larutan pati dalam buffer fosfat diinkubasi dengan variasi suhu yaitu $40^{\circ} \mathrm{C}, 50^{\circ} \mathrm{C}, 60^{\circ} \mathrm{C}$, dan $70^{\circ} \mathrm{C}$

\section{pH Optimum}

Hasil penentuan didapatkan $\mathrm{pH}$ optimum dari fraksi amilase adalah pada $\mathrm{pH} 6$ seperti pada Gambar 1.

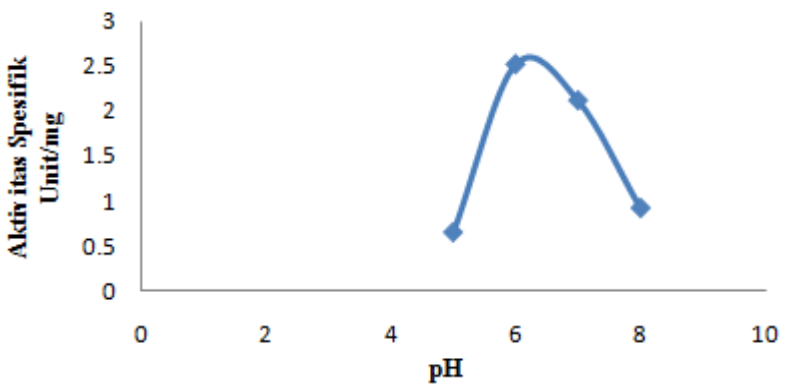

Gambar 1. Grafik pengaruh $\mathrm{pH}$ terhadap aktivitas spesifik amilase dari biji nangka

Dari grafik tersebut diketahui bahwa aktivitas amilase mencapai $\mathrm{pH}$ optimum 6 dengan aktivitas spesifik sebesar 2,52.

Unit/mg dan kembali menurun pada $\mathrm{pH}$ 7-8. Setiap enzim memiliki $\mathrm{pH}$ optimum dimana pada $\mathrm{pH}$ tersebut struktur tiga dimensinya paling kondusif untuk mengikat substrat. Jika konsentrasi ion hidrogen berubah dari konsentrasi optimal, maka aktivitas enzim secara progresif hilang hingga pada akhirnya enzim menjadi tidak aktif [13]. Aktivitas enzim menurun pada $\mathrm{pH}$ 7-8 karena berubahnya keadaan ion substrat dan enzim ${ }^{[14]}$. Perubahan tersebut dapat terjadi pada residu asam amino yang berfungsi untuk mempertahankan struktur tersier dan kuartener enzim aktif. Perubahan struktur tersier dapat mengakibatkan sisi hidrofobik yang awalnya tersimpan pada bagian dalam molekul enzim menjadi terbuka, sehingga kelarutan enzim berkurang. Berkurangnya kelarutan enzim dapat menurunkan aktivitas katalitik enzim secara perlahan.

\section{Suhu Optimum}

Nilai aktivitas amilase dari hasil penentuan suhu optimum dapat dilihat pada Gambar 2. Aktivitas amilase meningkat seiring dengan peningkatan suhu inkubasi, namun setelah mencapai suhu maksimum aktivitasnya menurun. Pada suhu $40^{\circ} \mathrm{C}$ aktivitas amilase dari biji nangka sebesar 1,99 Unit/mg sedangkan pada suhu $50^{\circ} \mathrm{C}$ aktivitas amilase mengalami peningkatan yaitu 2,52 Unit/mg, namun pada suhu $60^{\circ} \mathrm{C}$ dan $70^{\circ} \mathrm{C}$ mengalami penurunan yang cukup signifikan yaitu sebesar 1,59 Unit/mg. dari hasil ini didapatkan bahwa suhu optimum amilase dari biji nangka yaitu $50^{\circ} \mathrm{C}$.

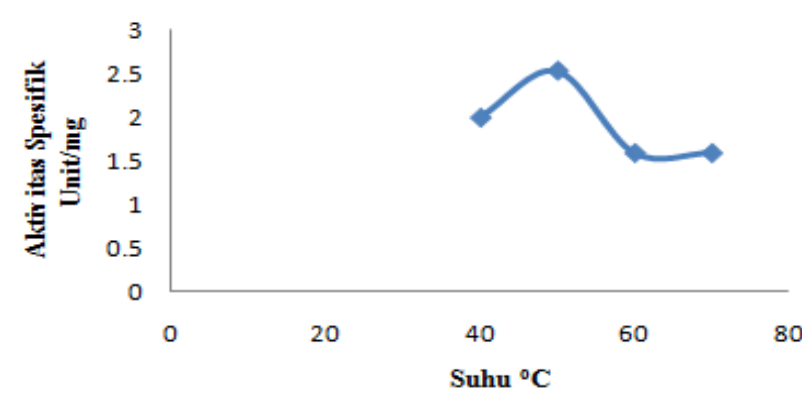

Gambar 2. Grafik pengaruh suhu terhadap aktivitas spesifik amilase

Enzim mempunyai suhu tertentu yang menyebabkan aktivitasnya mencapai keadaan optimum. Ketika suhu bertambah sampai suhu optimum, kecepatan reaksi enzim naik karena energi kinetik bertambah. Selain meningkatkan energi kinetik, bertambahnya suhu juga akan meningkatkan frekuensi tumbukan antara molekul enzim dan substrat, sehingga enzim menjadi aktif. Bertambahnya suhu yang melebihi batas suhu optimum dapat menyebabkan enzim terdenaturasi dan mematikan aktivitas katalisnya [14]. Suhu yang melebihi batas optimum juga akan menyebabkan substrat berubah konformasinya, sehingga substrat tidak dapat masuk kedalam sisi aktif enzim. Hal tersebut akan mengakibatkan aktivitas enzim turun karena tidak terbentuknya kompleks enzim substrat, sehingga konsentrasi enzim rendah.

\section{SIMPULAN}

Dari hasil penelitian yang telah dilakukan, dapat disimpulkan bahwa:

1. Aktivitas spesifik amilase ekstrak kasar pada suhu $4^{\circ} \mathrm{C}$ sebesar $1,50 \mathrm{U} / \mathrm{mg}$ dan pada suhu $20^{\circ} \mathrm{C}$ sebesar $1,99 \mathrm{U} / \mathrm{mg}$. Aktivitas spesifik amilase pada hasil fraksinasi yaitu pada fraksi $50 \%$ sebesar 2,12 Unit/mg, fraksi 55\% yaitu 1,904 Unit/mg dan fraksi $60 \%$ yaitu 1,67 Unit/mg.

2. $\mathrm{pH}$ optimum amilase pada fraksi $50 \%$ dari biji nangka yaitu pada $\mathrm{pH} 6$ dengan aktivitas spesifik sebesar 2,52 Unit/mg, sedangkan suhu optimum yaitu pada suhu $50^{\circ} \mathrm{C}$ dengan aktivitas spesifik 2,52 Unit/mg. 


\section{UCAPAN TERIMA KASIH}

Penulis mengucapkan terima kasih kepada semua pihak yang telah membantu, membimbing, dan mendukung selama proses penelitian dan penyusunan artikel ini.

\section{REFERENSI}

[1] Dessy Christina Sianturi, "Isolasi Bakteri dan Uji aktivitas Amilase Termofil Kasar dari Sumber Air Panas Penen Sibrubiru Sumatera Utara," Universitas Sumatera Utara, Medan, Tesis 2008.

[2] Prasanna V Aiyer, "Amylases and Their Application," African Journal of Biotechnology, vol. 4, no. 13, pp. 1525-1529, Desember 2005.

[3] Anna Poedjiadi and Titin Supriyanti, DasarDasar Biokimia. Jakarta, Indonesia: UI-Press, 2006.

[4] P M Gaman and K B Sherrington, Ilmu Pangan: Pengantar Ilmu Pangan, Nutrisi, dan Mikrobiologi, R B Kasmidjo, Ed. Yogyakarta, Indonesia: UGM-Press, 1992.

[5] Aflukwa C A, Ibiam U A, Edeogu C O, Nweke $\mathrm{F} \mathrm{N}$, and Chukwu U E, "Determination of Amylase Activity of Crude Extract From Partially Germinated Mango Seeds (Mangifera oraphila)," African Journal of Biotechnology, vol. 8, no. 14, pp. 32943296, July 2009.
[6] Zeily Nurachman, Alfredo Kono, Ocky Karna Radjasa, and Dessy Natalia, "Identification a Novel Raw-Starch-Degrading-a-Amylase from a Tropical Marine bacterium," American Journal of Biochemistry and Biotechnology, vol. 6, no. 4, pp. 300-306, 2010.

[7] Khairul Anam, "Pengukuran Kadar Protein dengan Fraksinasi Amilase dengan Metode Bradford," Institut Pertanian Bogor, Bogor, 2010.

[8] Mufti Mutia, Seniwati Dali, Rugaiyah Arfah, and Firdaus Zenta, "Isolasi dan Karakteristik Enzim Amilase dari Akar Rimpang AlangAlang (Imperata cylindrica)," 2013.

[9] Rani Gupta, Paresh Gigras, Harapriya Mohapatra, Vineet Kumar Goswami, and Bhavna Chauhan, "Microbial $\alpha$-Amylases: A Biotechnological Perspective," Process Biochemistry, pp. 1-18, 2003.

[10] Scopes , Protein purification. New York: Spinger Verlag, 1982.

[11] Lehninger , Dasar-Dasar Biokimia. Jakarta, Indonesia: Erlangga, 2008.

[12] R J Fessenden and J S Fessenden, Kimia Organik Jilid 1, 3rd ed. Jakarta, Indonesia: Erlangga, 1994.

[13] M N Shahib, Biologi Molekuler Jilid 1. Bandung: Fakultas Kedokteran UNPAD, 2005.

[14] S R Iswari and A Yuniastuti, Biokimia. Yogyakarta, Indonesia: Graha Ilmu, 2006. 